\title{
MYCORRHIZAL FUNGI OF ENDANGERED ORCHID SPECIES IN KOLLI, A PART OF EASTERN GHAT'S, SOUTH INDIA
}

\author{
S. SENTHILKUMAR \\ Department of Botany, St. Joseph's College (Autonomous) \\ Tiruchirappalli-620 002, S. India. senkumar68@yahoo.co.in
}

The fascinating orchid flowers exhibit diversity in shape, structure, size, colour and fragrance which also account for multimillion dollar floriculture trade worldwide. The importance of mycorrhizal infection for the germination of orchid seeds and for successful development is well established. Orchid mycorrhizas are the most ancient and widespread symbiotic partners of both terrestrial and epiphytic form of orchids. We are only beginning to understand the morphological, biochemical and molecular events which form the basis for the symbiotic interaction of mycorrhizas with the roots of their host plants. The availability of sources easily amendable to the former have given a strong impetus to mycorrhizal research (Senthilkumar 2001). Infection is reported to be common in the roots of temperate species, but in tropical conditions the situation is not so clear. With the rapid development of agriculture and commercialization, the ecosystem in Kolli is already disturbed. Many orchid species in India are considered to be endangered; however, no comprehensive account is available on the orchid wealth of Kolli (an area of $503.42 \mathrm{~km}^{2}$ lying between $11^{\circ} 00^{\prime} 00^{\prime \prime}$ to $11^{\circ} 25^{\prime} 00^{\prime \prime} \mathrm{N}$ and $78^{\circ} 15^{\prime} 00^{\prime \prime}$ to $\left.78^{\circ} 30^{\prime} 00^{\prime \prime} \mathrm{E}\right)$ that forms the second richest source in India.

Healthy roots from the endangered orchid species viz. Gastrochilus acaulis, Polystachya concreta and Nervilia prainiana were collected from the Kolli hills. The roots of the former were cultured in potato dextrose agar (PDA). The cultured fungus were identified using the methodology provided by Sneh et al. (1991) belonging to Rhizoctonia. The moot point, however, is whether the fungus enters the host through root hairs or through velamen cells. Peterson and Currah (1990) have shown that hyphae were frequently present at the apex of epidermal hair initials of protocorm and around elongating hairs. Entry exclusively through the root hairs or through velamen or through both these routes is likely to be dependent on the structure of the involved root, especially the loci of exodermal passage cells. In fact the exodermal passage cells do not have a control of entry of fungi into the cortex (Peterson 1988), which remain the only living cells of the exodermis, and those cell walls do not have lignin and suberin, at least to the extent that other exodermal cells have (Esnault et al. 1994).

The degree of infection by the fungus is invariably estimated by calculating the infection density with the formula provided by Hadley and Williamson (1972). Observations of the colonization in Nervilia showed the maximum percentage of cells colonized by $R$. solani followed by Gastrochilus and Polystachya. The degree of infection was reported to vary in the same orchid in different seasons of the year by some of the earlier investigations. Benzing (1982) also reported that all roots which are in contact with the substrate were infected in an epiphytic orchid of Florida. In other words, heterotrophy or otherwise of the orchid species, does not appear to have a deciding effect on the periodicity of infection or on the intensity of infection.

Since infection is a continuous process in an orchid and since all the cells of the cortex are not colonized at the same time, in a mature root there was often a mix up of younger and older colonization across the entire cortex. In other words, in older roots there is no spatial restriction of younger and older colonisations in the cortex. However, Hadley (1975) had also come to a conclusion similar to that by the present worker when he reported that in many orchids a clear spatial separation into 'digestion' and 'host cells' could not be seen and that all infected cells will at one time or another be converted into the so called 'digestion 
cells'. The oldest pelotons were the first to act as digestion cells, and this was followed by cells with subsequent colonization. In other words, between colonisation and the process of onset of digestion there was a definite interval. A gradient of fungal digestion with more to less intensity was also observed from outer to inner cortical cells in some South East Himalayan orchids by Katiyar et al. (1985).

One of the observations made in this study pertains to the separation of lysing pelotons from the rest of the host cytoplasm. Controlled histochemical studies made at present in all three studied species have categorically shown that this layer, to start with, was discontinuously initiated and subsequently invested all round the lysing pelotons, the callosic material was evident until very late stages in the lysis of the pelotons (Peterson \& Currah 1990, Senthilkumar \& Krishnamurthy 1999). The method of lysis may also aid in the separation of orchid mycorrhiza from other types of mycorrhiza and to conduct studies under more natural conditions.

\section{LITERATURE CITED}

Benzing, D. H. 1982. Mycorrhizal infection of epiphytic orchids in Southern Florida. Amer. Orch. Soc. Bull. 51: 618-622.

Esnault, A. L., G. Masuhara \& P.A. McGee. 1994. Involvement of exodermal passage cells in mycorrhizal infection of some orchids. Mycol. Res. 98: 672-676.

Hadley, G. 1975. Endomycorrhizas. Academic Press, London.

Hadley, G. \& B. Williamson. 1972. Features of mycorrhizal infection in some Malayan orchids. New Phytol. 71: 111-118.

Katiyar, R. S., G.D. Sharma \& R.R. Mishra. 1985. Biology, conservation and culture of Orchids. East West Press, New Delhi.

Peterson, C. A. 1988. Exodermal Casparian bands for ion uptake by roots. Physiol. Plant. 72: 204-208.

Peterson, R. L. \& R.S. Currah. 1990. Synthesis of mycorrhizae between protocorms of Goodyera repens and Ceratobasidium cerelae. Can. J. Bot. 68: 1117-1125.

Senthilkumar, S. 2001. Problems and prospects of orchid mycorrhizal research. J. Orch. Soc. India 15: 23-32.

Senthilkumar, S. \& K.V. Krishnamurthy. 1999. Nuclear changes in host cells colonized by orchid mycorrhizae. Biol. Plant. 41: 111-119.

Sneh, B., L. Burpee \& A. Ogoshi. 1991. Identification of Rhizoctonia species. APS Press,USA.

S. Senthilkumar is a lecturer in Botany, St Joseph's College (Autonomous), Tiruchirappalli, S. India, well trained in orchid mycorrhizal systems. He has been awarded as a Young Scientist by the Department of Science and Technology, Government of India, for the year 2001, Young Scientist Bursary award from the Royal Microscopical Society, Cambridge University, for the year 2001, and Young Scientist Grant from the International Mycological Society, USA, for the year 2002. He has published nearly 48 research papers in national and international journals and presented 30 papers in Conferences/Symposia. He has also been awarded with two major projects by the Department of Science and Technology, Government of India in 2001 and 2003 on the orchid mycorrhizal system. During 10 years of active research, he has been the author of two books viz. "Biotechnology of Orchids" and "Laboratory Manual of Molecular Biology". Man of the Year 2002 has been received from the International Biographical Institute, USA, for his outstanding contribution to Plant Sciences. 